\title{
Trump's Wall: A Monument of (Un)Civil Religion?
}

\section{Lloyd Barba}

In an era of deep soul searching, many have taken it upon themselves to right our nation's commemorative record by removing public monuments that honor Confederate generals. Among the most notable critics of these recent undertakings is President Trump, calling these material markers (of the likes of Robert E. Lee and Stonewall Jackson) "beautiful" and accusing the iconoclasts of ripping apart "the history and

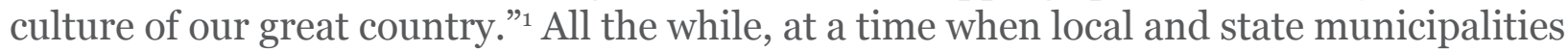
are deciding on the fate of controversial statues, Trump has relentlessly pushed for a "monument" that could not be torn down or simply relocated: the wall. ${ }^{2}$

\section{Civil Religion}

The rhetoric and rituals surrounding the wall suggest that the President is proposing the wall as a monument in honor of a particular kind of "civil religion." Trump speaks from the nation's most powerful platform, according him a measure of influence that others do not possess. Because of this, he receives massive support and his policies, once passed, are those of the nation, though they might not reflect the sentiments of many people. The wall itself is designed, quite literally, to divide people; nobody contests this point. Given the divisive nature of his form of nationalism, his throngs of "court evangelicals," variegated rituals buttressing his rhetoric, and his presidential power to materialize his beliefs, those who oppose Trump may very well label his brand of civil religion as uncivil religion. ${ }^{3}$ His wall brings into sharp relief the contested nature of monuments that use division as a marker of national unity.

The term "civil religion" came into popular use in the late-twentieth century, courtesy of sociologist Robert Bellah's 1967 groundbreaking essay "Civil Religion in America." 4 Bellah's deft deployment of the term to describe the beliefs, symbols, and rituals of the U.S.'s public quasi-religion helps us make sense of the veneration of certain people (Washington and Lincoln) and places (Arlington National Cemetery). Rituals (the recitation of the Pledge of Allegiance at the start of school and games) and music (the national anthem) undergird the gravity of this American civil religion and in effect deify heroes and sacralize places.

The concept sparked debates for the next half century over the limits and possibility of its application. Some scholars have opted for more nuanced terms such as "religious nationalism," "American civic imaginaries," "American legitimating myths," or, the more regionally attuned "Southern civil religion." ${ }^{\text {T }}$ The impact of the term is hard to overstate considering that Bellah's article "ranks as one of the most influential essays in the whole study of Religion" with very few other concepts having accomplished a "quicker transition from the nation's scholarly journals to its op-ed pages." 6 The sheer number of attempts to work with, against, and despite the term, establishes that there is no consensus on the term. Bellah himself, by the early 1990s, had grown frustrated 
by the debate and exceptions "bogging down into arguments over definition that the substance was being overlooked." 7 But the lack of any single universal definition (a futile attempt in my own opinion), should not discourage us from using the term to describe something loosely and nationally recognizable and the religious dynamics that Bellah first observed in a decade of tumultuous societal changes. His basic idea, namely that there exists a form of civil religion that is imbued with transcendent values, has proven helpful in examining how we view the discourses of American religion, politics, and public life.

The debates regarding civil religion have also prompted scholars to consider the kinds of civil religion, especially with respect to politics. To be sure, Bellah, writing his original article in the thick of the Civil Rights Movement, noted that civil religion "has not always been invoked in favor of worthy causes" and offered the religiosity of the radical right in that era as an example. Politics at play influenced the core of the critiques and kinds of civil religion, leading historian Amanda Porterfield to point out the "inevitably partisan nature of civil religion." "Sociologist Robert Wuthnow in 1988 identified "deeply divided" forms of American civil religion that ranged from "liberal" to "conservative" which "seem to have very little of substance in common." More recently, sociologist Philip Gorski imagines the debate about the place of "civil religion" in U.S. society more on a spectrum in which neither group on each end (Radical Secularism on the left and Religious Nationalism on the right) does justice to the term "civil religion" or acts in the best interest of a "prophetic republicanism." ${ }^{10}$ None of these formulations of the kinds of civil religion necessarily result in the exclusions of multiple kinds of civil religions existing at the same time and same place. Historian Arthur Remillard argues that "civil religious diversity" existed in a place as racially and religious repressive as the Wire Grass Gulf South in the Post-Reconstruction Era where a white protestant version of civil religion dominated over ones articulated by African-American Protestants and Euro-American Catholics and Jews. ${ }^{11}$ Regardless of the kind, a dominant form of civil religion bears material consequences. Trump's proposed wall would be among the most material yet.

\section{Trump's Brand of Civil Religion}

But how exactly does Trump espouse a civil religion? To answer this, I propose that, like many have done over the past half century, we return to Bellah. But instead of arriving in 1967, we land in 1987 to recover and reimagine the term he coined with Frederick Greenspahn, "uncivil religion," as something more than interreligious hostility. ${ }^{12}$ If civil religion is meant to unite the nation, uncivil religion accomplishes the contrary. Unlike civil religion which is supposed to be above the government and always able to critique its missteps, uncivil religion offers its reigns to divisive discourses. Impact matters here more than intention. I am not suggesting that any gesture of civil religion ever goes without opposition; but the sheer number of religious and human rights groups that have decried the building of Trump's wall, indeed suggest that he deploys something peculiar that is more of an instrument of divisions than of unity.

How is his wall a monument to this form of (un)civil religion? 


\section{The Size and Scale of Monuments}

The long-term domination of any one civil religion results in an alteration of landscape through monument making. Monuments are never made merely to commemorate; they are built to display power. First, to return to the imagery of monuments in the post-bellum South, a place and time in which defeated Confederates would fuse the power of history and religion to "form a story of the use of the past as the basis of a Southern religious-moral identity." ${ }^{13}$ Shapers of the southern civil religion (in large part the United Daughters of the Confederacy) turned to monument making as a way to cement the legacy of the Lost Cause. Historian Charles Regan Wilson argued that the period from 1890 to 1920 marked the "South's monument-making obsession." ${ }^{14}$ A 2016 study by the Southern Poverty Law Center on Confederate symbols demonstrates that the first and larger wave swelled from 1895-1920, an era marked by the U.S Supreme Court decision on Plessey $v$ Ferguson, the crafting and enacting of Jim Crow laws, and resurgence of the second KKK. Thirty-five years after the end of the Civil War, the Lost Cause had been firmly rooted in the minds of white southerners, and as older veterans of the Confederate Army began to pass away, Lost Cause believers ensured that the perceived heroism of veterans would not slip away too. The second, but comparatively much smaller wave of monument dedication, transpired from 1950 to the 1960 s as the Civil Rights movements made headway in de-segregating the South and as the first century since the Civil War had passed. Studies today have identified at least 718 monuments in the U.S., 95\% of which are in Southern states. ${ }^{15}$ Monuments are not mere reminders as much as they are shapers of interpretation and ideology. In these ways they monumentally change how landscape is beheld, and, in the case of the Lost Cause, sacralized.

Size matters. The physical dimensions of any monument speak to intent of ideological shaping. Larger than life busts and statues, for example, exude leadership, dominance, and a sense of permanency. Since its inception, Stone Mountain, the largest of all Confederate memorials and the largest relief sculpture in the world, received a host of support from numerous private and public coffers to erect a monument unlike any other in terms of size and historical interpretation. At the dedication of Stone Mountain, the KKK held initiation ceremonies, kickstarting a long trajectory of white supremacy as the ideological bedrock etched onto the granite stone. Early supporters and original architect Gutzon Borglum openly discussed the possibility of including Klansmen into the monument alongside the Confederate Generals. After nearly four decades of no work on the memorial, the project resumed in 1964 at the behest of the state of Georgia's neo-Confederates that lashed out against the Civil Rights movement. ${ }^{16}$ Memorials such as Stone Mountain or even Borglum's later project Mount Rushmore offer fine examples of how the natural landscaped can be physically altered into objects that connote power and dominance of one people group over another, be they in the segregated South or the Black Hills of North Dakota. (Lest we think that the wars over monument size don't matter, bear in mind the long ongoing carving out of the Crazy Horse monument, set to tower nearby Mount Rushmore and speak back to the Rushmore's encroachment onto Native land). ${ }^{17}$ While carving into existing stone can certainly be a project of racist and settler colonialist ideology, moving millions of tons of steel and dirt from a quarry 
(or mountain) to build a wall is another display of power, a show of power that Trump initially estimated to be easily achieved under his control. When asked by a reporter in

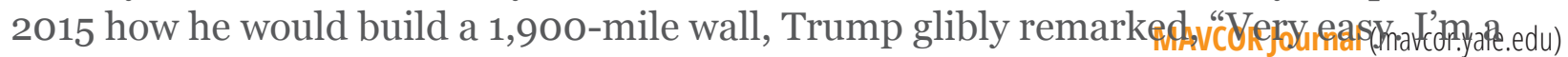
builder. That's easy. I build buildings that are-can I tell you what's more complicated? What's more complicated is building a building that's 95 stories tall. O.K.?”18

With the completion of the wall, Trump will be joining a list of presidents who undertook massive, landscape altering, construction projects. But the wall is in a category of its own. First, as variously proposed, the wall will be Trump's greatest physical marker in terms of size, volume, weight, length, etc. Hoover has his Dam and Eisenhower his Interstate System, but as a material object, Trump's wall (in its various proposed iterations) would rival these massive alterations to the physical landscape. The fervency with which Trump has pursued his monument surpasses the other concrete behemoths. While Clinton started building thirteen miles of the wall and Bush later erected over 600 miles of more walls, neither of the two made the wall a hallmark of his presidential campaign or fixated on it as Trump has and will continue to do. As one of the largest building projects to enjoy such steadfast Presidential support, the wall has figured as a synecdoche for Trump himself, a material and discursive monument of what his presidency stands for.

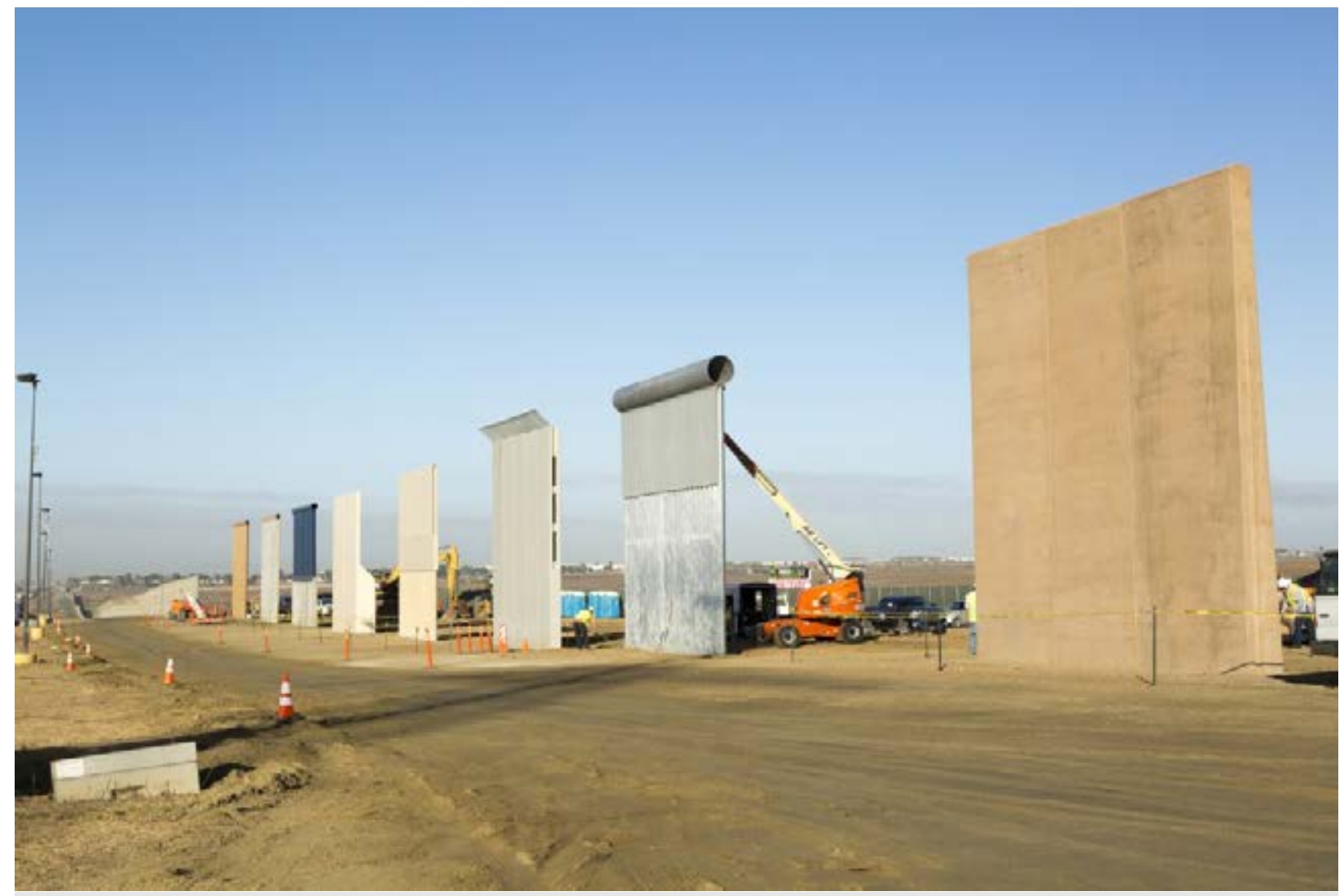

As of late July 2019, funding for 336 miles of wall has been secured in large part due to Trump's declaration of a state of emergency. Most of the wall will, in fact, be replacement wall. Construction on new and replacement wall commenced in 2019 in the Rio Grande Valley of Texas and San Diego. This October 2017 photograph taken in San Diego showcases some of the prototypes of Trump's wall. These prototypes have since been demolished to make way for a federally funded wall. ${ }^{19}$ (Photo credit: Mani Albrecht, Customs Border Patrol) 
The wall has figured prominently in Trump's most formative moments as a presidential candidate and now Commander-in-Chief. It took him no longer than two minutes in his announcement of his presidential bid to broach the threat of Mexico and the kinds of people crossing over. His solution to this problem, as revealed later in his speech, was a wall, but not just any wall. He boasted: "I will build a great wall-and nobody builds walls better than me, believe me-and I'll build them very inexpensively. I will build a great, great wall on our southern border, and I will make Mexico pay for that wall. Mark my words." ${ }^{20}$ His rhetoric about his monument is, to say the least, superlative. The rituals of his kind of (un)civil religion are a case in point.

\section{The Wall and Its Rituals}

The wall, like other instantiations of American civil religion, is upheld with rituals. Chief among these is the routine mantra "Build the Wall" that devotees at his rallies regularly chant with frenzied fervor. They chant this while wearing the red hats that spell out the (un)civil religion's most notable doctrine, "Make America Great Again.” To make America great again, Trump and his base maintain that a wall must be built both to keep others out and to keep those within safe. He describes the implementation of these safeguards as his "sacred duty" and "sacred obligation."

Trump's address to the nation on January 8, 2019 (amid the government's longest shutdown) focused on his campaign's most noted promise: securing the border. In his rhetorical moves, Trump envisions himself as a protector or shepherd (dare I say, "pastor") of the American people purportedly under a threat. The wall is of such importance to the protector Trump that, in early January 2019, he broached the possibility of declaring the "border crisis" a national emergency should Congress fail to fund his wall. ${ }^{22}$ A month later he declared the official "National Emergency Concerning the Southern Border in the United States." The protector-pastor keeps close a cadre of "court Evangelicals" who hail him as a modern-day Nehemiah, the ancient Hebrew politician made famous for building a wall around Jerusalem. On the morning of his inauguration, Trump (like many presidents have done) partook in a private religious ceremony at St. John's Episcopal church, a stone's throw from the White House. In an unusual twist to the typical homilies delivered for such an occasion, the minister that morning Robert Jeffress pronounced that "God is not against building walls." ${ }^{23}$ In a renewed wave of xenophobic (and contextually unsound) interpretation in early January 2019, Jeffress's pronouncements crested in declaring that " $t \mathrm{t}] \mathrm{he}$ Bible says even Heaven itself is going to have a wall around it." ${ }^{24}$ Clearly, adherents of Trump's (un)civil religion have ascribed biblical significance to Trump and his monument.

Bellah maintained that "the theme of sacrifice was indelibly written into the civil religion." ${ }^{25}$ Trump's latest justification for immediate action to fund and build the wall especially concerns sacrifice. While Trump does not boast a role as Commander-in-Chief in memorable wars fought on American soil (e.g., the American Revolution or the Civil War) the border has become his battlefield. In his address to the nation on January 8, 2019, he cited the macabre details of recent deaths at the hands of "illegal alien(s)." Some of the Trump faithful have opined that the President in his televised address 
ought to have shown images of these victims who, they believe, would still be alive if the wall had been in place (a publicity move in keeping with Trump's tactics). ${ }^{26}$ Other more strident supporters have produced images of the wall being built with the names of the victims on each panel. The devotion to the (un)civil religion led the president himself to "politicize the death" (a foul-play usually called on supporters of gun-control in wake of mass shootings) of California Police Corporal Ronil Singh, a Fijian immigrant himself shot by an undocumented Mexican. The gravity of the wall outweighs the typical and civil waiting period to politicize deaths. The devotees of the (un)civil religion see these lamentable and unfortunate deaths as clear clarion calls to sacrifice their own livelihood for the sake of seeing the wall materialize. Trump agrees. Following his address to the nation on January 8, Trump visited border sites in McAllen, Texas and declared that without the border there would be "death, a lot of death." ${ }^{27}$ The wall then, functions as a titanic translocal tombstone that marks, remembers, and relentlessly politicizes the tragic deaths of those whose lives were cut short. Such sanguinary justifications are not altogether unfamiliar to the discourses surrounding civil religions. We are reminded that the Lost Cause operated as one that was "not dedicated to honoring the American nation;" on the contrary it was "a cult of the dead which dealt with essential religious concerns." ${ }^{28}$ Trump promotes a kind of civil religion that Gorski describes as "American religious nationalism." ${ }^{29}$ Moreover, the President's brand of nationalism fits squarely within the conquest narratives that bolster his sense of nationhood. Given that the "conquest narratives" of nationalistic civil religion are fueled by stories of bloodshed and sacrifice, it should be little surprise to find that Trump appeals to blood so frequently in his justifications for border security, namely wall building. ${ }^{30}$ The loss of American lives frame his wall efforts as a struggle between a transcendent good and preventable evil, calling his supporters who are parents of the slain "Angel Parents." While ignoring how the current walls have for decades now rerouted migrants further into the desert resulting in a "land of open graves" dotted with the bodies of over 3,000 deceased migrants, Trump assures that building the wall will stanch the (read: American) bloodshed, making the wall a monument of salvific power. ${ }^{31}$

The fascination with the wall has also solidified in the form of monetary sacrifice. Wall believers have taken up an offering. Within two weeks of Trump's January $8^{\text {th }}$ speech on border security, supporters on the GoFundMe page "We the People Will Fund the Wall" raised over 20.5 million. Though the funds were not ultimately offered to the federal government, as of mid-July donations continue to pour in (now just over 25 million), making it the most lucrative campaign in the website's history. Sacrificial giving for the monument ranges from a few dollars to $\$ 50,000$ averaging well over $\$ 50$ per donation..$^{32}$ The frenzy generated across different media indeed demonstrates the spectacular power of ritual and rhetoric to mobilize offerings.

The funding for the wall highlights how ritual authority (à la historian of religion Kathryn Lofton's analysis) can be coopted by lay practitioners. ${ }^{33}$ A citizen's group, We Build the Wall, completed nearly half a mile wall made of 18 -feet high steel bollards in Sunland Park, New Mexico. Using the money generated from the aforementioned GoFundMe page, the group triumphs "We BUILT the Wall," breathing life in the vitiated efforts of the federal government. To suggest that We Build the Wall has trumped up the 
effect of its effort is no exaggeration. Its leader and spokesperson Brian Kolfage claims:

In this small section of border U.S. Border Patrol public affairs office stated that over 1000 people cross each day on average, and over $\$ 200 \mathrm{k}-\$ 300 \mathrm{k}$ worth of illegal drugs enter America. This is a vital smuggling route for the most ruthless cartel, the Juarez Cartel. Who murdered thousands of innocent civilians and journalist and trafficked sex slaves across our border. WE ARE STOPPING THEM NOW..$^{34}$

Moreover, Kolfage boasts that his team can complete the wall for a fraction of the cost and time that the government can. His invectives against the inefficiency of the federal government to mobilize wall building are no criticism of Trump himself. On the contrary, Kolfage glories at the fact that "[e]ven the New York Times had to report that President Trump gave our project his blessing." 35 The religious elements of the language should not be understated. The ritual of wall offerings has been commensurate with the ritual of building, complete with a ribbon-cutting ceremony and continued fund raisers. Where officialdom has been unable to bring the project to fruition, lay practitioners have made the ritual gestures.

This showdown in Sunland Park serves as a reminder that the wall packs much more symbolism than security. While the Mayor of Sunland Park brought the project to a halt on the grounds of technical building violations, New Mexico's Governor Michelle Lujan Grisham has been among one of many to criticize the group's effort. She claims that it neither aided in securing the border or alleviated the humanitarian crisis. Further, it does not appear to have been built at a high priority site, again showing how this wall functions more as a symbol to display division. ${ }^{36}$ 


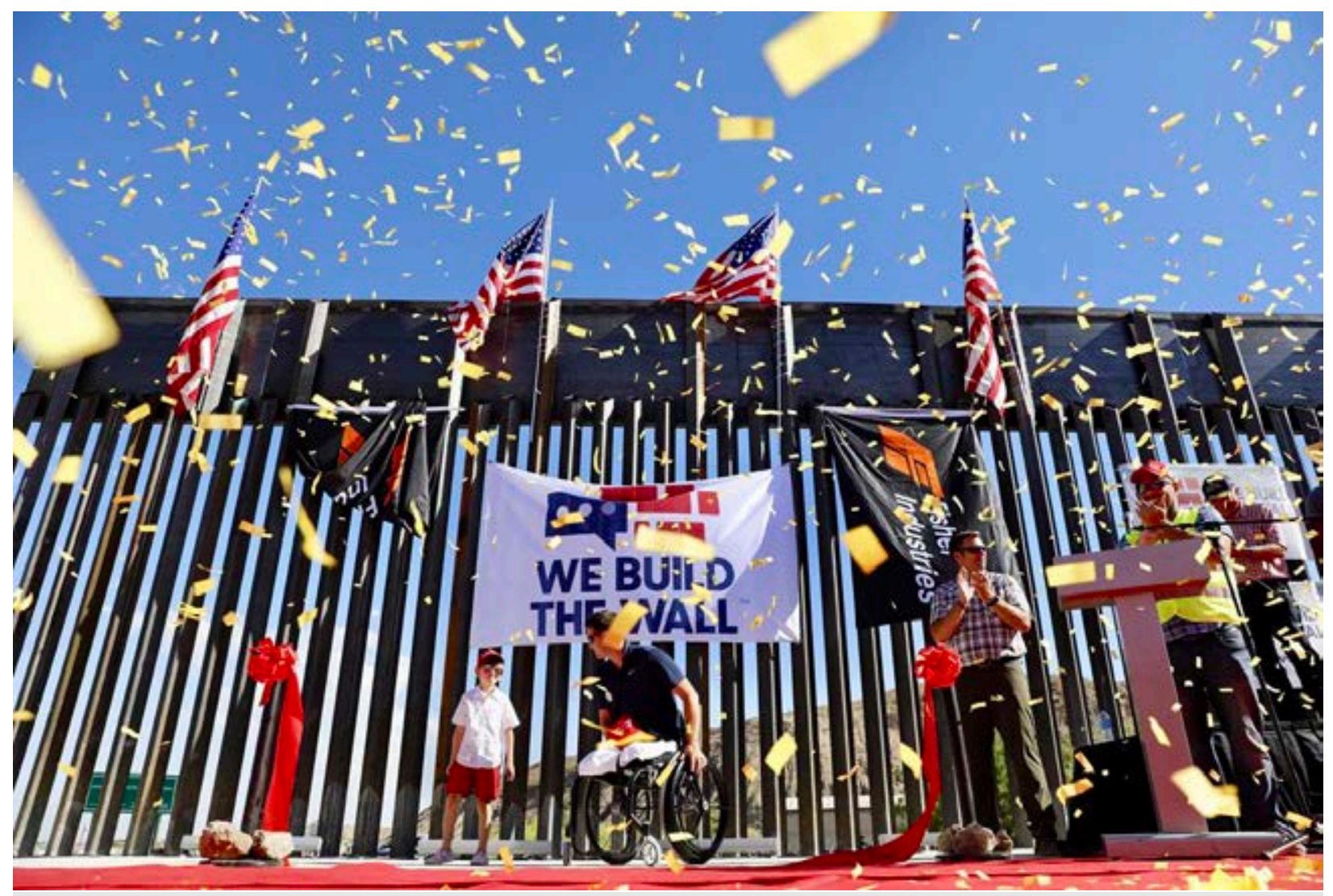

We Build the Wall founder, Brian Kolfage is pictured here at the ribbon-cutting ceremony of his organization's privately funded wall in Sunland Park, New Mexico. Never critical of Trump, the group has bypassed the federal government's gridlock. In reality, however, Trump has already erected more brand-new and replacement wall than We Build the Wall has, sans the jubilation as captured here in this photograph. (Photo credit: Ivan Pierre Aguirre for The Texas Tribune.)

\section{The Wall and Its Aesthetics}

As among the busiest and most contrasting international border, the U.S.-Mexico border constitutes a "hyperborder." ${ }^{37}$ As such it merits considerable attention and imagination complete with its own set of aesthetics.

While the wall itself may not appear to be a religious object, it is nevertheless a canvas onto which civic groups and political interests may inscribe volumes of religious meaning. Just as in the South where the industrialization of rural towns did the "civil religious task of inscribing sacred meaning onto physical structures," so, too, do Trump and his base carry out a similar task with respect to the wall. ${ }^{38}$ Lofton provokes us to consider a host of objects that are not religious in and of themselves but are "critical object[s] in the sensorium of modern religious experience." ${ }^{9} 9$ The wall, as a prominent object in popular culture owing in large part to Trump's advocacy, constitutes one of the most divisive debates in contemporary American discourses.

Trump's (un)civil religion, complete with an imagined wall, rituals, and rhetoric, has also assumed an aesthetic dimension. We can indeed "describe civil religion in terms of particular feelings and sensations," as art historian and scholar of religion David Morgan has prodded scholars to do. $4^{40}$ We Build the Wall relies heavily on images of Trump, claiming the imprimatur of their work being "Trump Approved." Let us not 
forget the initial aesthetic of Trump and the wall, as the first time he donned in public a "Make America Great Again" cap was at his campaign announcement, which he made in Laredo about building a wall. (His message subsequently won him the support of the Border Patrol agent union, the first union in America to support him.) $)^{41}$ Nor should we ignore how Trump revels in how others manifest the sentiments of wall devotion through dress. At a Pennsylvania re-election rally in May of this year, Trump invited to the stage a man from San Diego adorned in a brick-wall suit and tie and red "Make America Great Again" hat. The Build the Wall organization operates on similar energy, further borrowing the Trump brand by reeling in the support of Steven Bannon, his former Special Assistant, to participate in "Wall-A-Thon" live-streamed fundraising events..$^{42}$ Red, white, and blue color much of the merchandise (e.g., shirts, hats, coffee mugs, clocks, and phone cases). The terms "We Build the Wall" as well as Trump's image and the group's logo of a brick wall in construction form recognizable visual cues, revealing the discursive affinity between Trump, the wall, and nationalism. Donors who contribute in amounts between $\$ 100$ to $\$ 1,000$ can choose to have their personal or company's name etched onto a brick or bollards. ${ }^{43}$ We are only left to wonder what messages supporters would inscribe onto portions of the gifted wall if they were allowed to do so.

We Build the Wall promulgates its mission by deploying the rhetoric and imagery of the colors of American Patriotism and militarism in strategic ways. The "military-grade coffee" available for sale on its website awakens one to a larger reality of the militaristic moods taken on by supporters, guards on site, and the leadership team (many of whom boast years of extensive military experience). The aesthetics of the border wall send clear marching orders to its rank-and-file: there is an enemy (those entering through Mexico) and a warzone (the border). Such defining (that is, through opposition) is not altogether beyond the norm of civil religion. Islamic Studies scholar Ebrahim Moosa reminds us how "Bellah's civil religion finds its genealogy in a discourse of alterity; that is, with reference to those things to which American was opposed: British colonialism, slavery, and its cold war adversaries." 44 (We may very well add Muslims to this list in the post 9/11 hysteria, a frenzied fire that Trump further fueled with the declaration of the so-called Muslim Travel Ban.) Trump's decision to send 5,600 troops to the border in fall 2018 as part of Operation Faithful Patriot made the border a bona fide battle. ${ }^{45}$ Furthermore, the national emergency at the border he declared in mid-February 2019 turned the entire nation's attention to the conflict zone. From July to August 2019, the Trump administration approved of an increase in the number of U.S. military personnel and the deployment of predator drones, all in hopes of keeping troops and equipment at the border until September 2020. Approximately 5,000 service members remain at the border to reinforce the numerous quasi-military styled Customs and Border Patrol officials and the armed-civilian militia groups; but, with an estimated 2,100 more to be sent in late summer, the boots on the ground are likely to reach an all-time high at the border. ${ }^{46}$ Mere snapshots of the building and guarding of the wall display it as an object of full-throttled fusion of militarism and patriotism. 


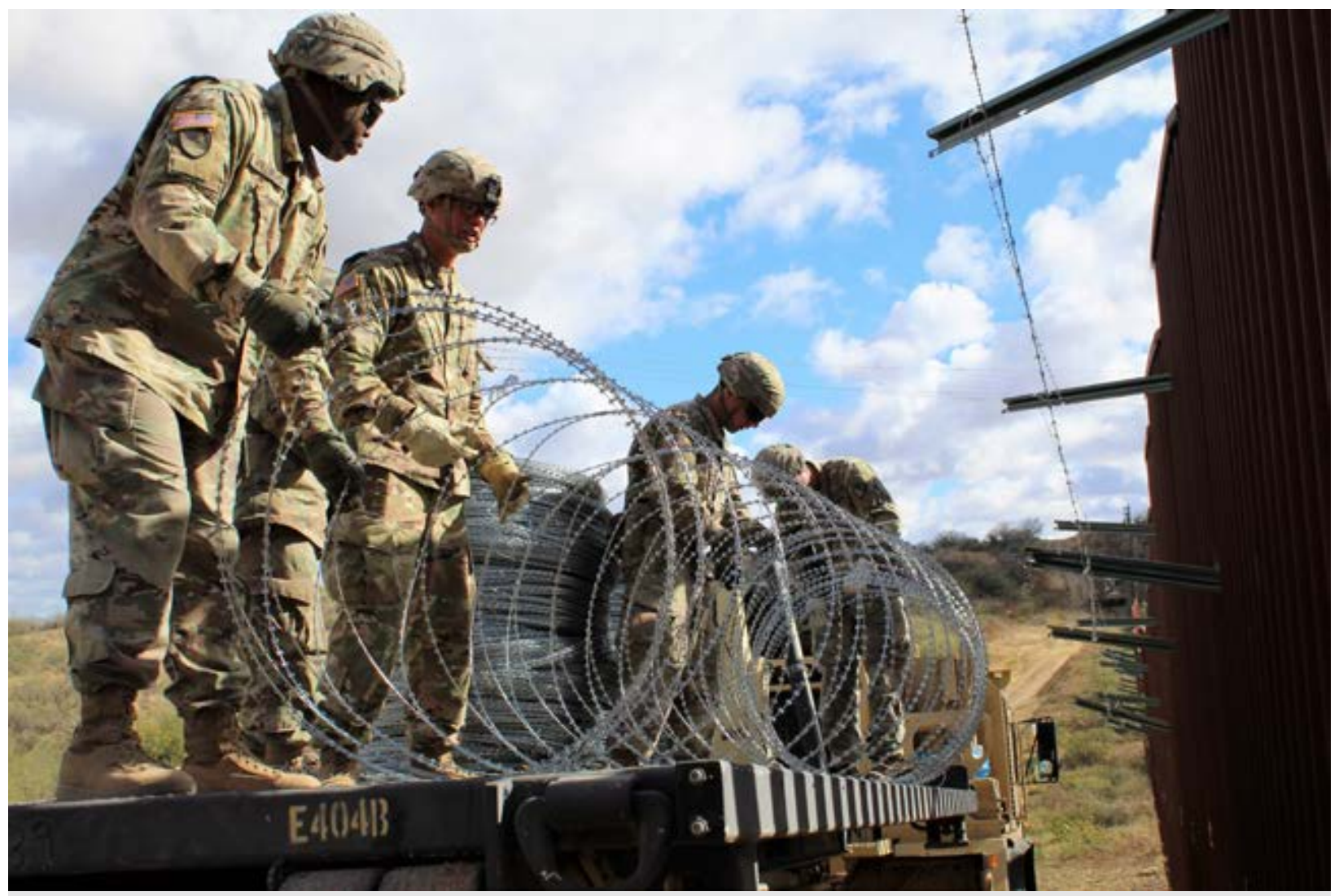

Engineers from the $937^{\text {th }}$ Clearance Company, pictured above, install concertina wire on the border in Arizona. The presence of citizen-led wall building campaigns, civilian militia groups, the personnel of the various agencies tasked with protecting the border and deporting the undocumented, and now the U.S. military, cements the fusion of a militarized-patriotic aesthetic into the popular imagination of the wall. (Photo: Corey Maisch, U.S. Army)

Grandiose gestures are the performative foundation of monument making in any manifestation of American civil religion. The business of the border wall, like most of Trump's undertakings, is big. Border protection is a massive industry. "We spend more already on border and immigration protection than the combined budget of the FBI, the ATF, the U.S. Marshals, the Secret Service, and the entire budget of the NYPD," calculated historian Garrett Graff. ${ }^{47}$ If Trump could have it his way, the wall would cover nearly 2,000 miles and range in height. In 2015, he commented on why and how he is especially fit to deliver the "Trump wall":

"I will build the greatest wall that you've ever seen ... I'm a great builder. What do I best in life, I build. Your infrastructure is crumbling. Isn't it nice to have a builder? A real builder. So you take precast plank. It comes 30 feet long, 40 feet long, 50 feet long. You see the highways where they can span 50, 6o feet, even longer than that, right? And do you a beautiful nice precast plank with beautiful everything. Just perfect. I want it to be so beautiful because maybe someday they'll call it The Trump Wall. Maybe. So I have to make sure it's beautiful, right? I'll be very proud of that wall. If they call at this The Trump Wall, it has to be beautiful." 48 
Depending on its design, the wall could cost anywhere between 8 to 70 billion dollars. ${ }^{49}$ Realizing the infeasibility of this, he has moderated his proposal to something that still is not quite so modest. Most of the wall currently under construction stands no higher than 18 feet, but this may only be the beginning of something much bigger. Trump's national emergency called for 8 billion dollars to be redirected from other projects and funneled into his wall. Plaintiffs in Sierra Club and Southern Border Communities Coalition $v$ Trump seek to delay or altogether halt further construction. Lawyers in the case cited the misuse of funds within Trump's proposal, as section 8005 of the Department of Defense Appropriation Act of 2019 only allows transfers of funds for "unforeseen military requirements" (such as when the military is brought in to provide aid for catastrophic weather events). Trump and wall supporters then assert that the crisis at the border is tantamount to an unforeseen military requirement. The Supreme Court's July 26, 2019 5-4 ruling allows for the Trump administration to use up to 2.5 billion dollars to fund the wall while litigation continues. Upon receiving word of the ruling, Trump tweeted: "Wow! Big VICTORY on the Wall. The United States Supreme Court overturns lower court injunction, allows Southern Border Wall to proceed. Big WIN for Border Security and the Rule of Law!" $5^{\circ}$ While the ruling is only temporary and his tweet perhaps overstated, the ruling represents his administration's furthest progress into wall building. ${ }^{.1}$ Such celebration is necessary to sustain the energy of Trump's (un)civil religion and the sacred duty that call him to fund and build the wall.

\section{(In)Conclusion}

Sacred duty also summons others to resist efforts to build the wall. While detractors of the wall would perhaps argue that Trump's (un)civil religion is characterized by "unworthy causes," almost all can fairly observe how it's a "deeply divided" partisan issue of civil religion. Sacred sites are at the center of disputes regarding the proposed routes of the wall. Leaders of the Tohono O'odam Nation bucked at Trump's intention to build a 75-mile wall that would cut clear across their sovereign land and sacred sites. ${ }^{52}$ Rev. Roy Snipes of La Lomita Chapel believes that the prospect of building the wall is "meant to intimidate people from the other side who might want to come across." ${ }^{3}$ Snipes's church stands on a site to be divided and handed over to the control of the Border Patrol according to recent wall plans. The disputes surrounding the building of the wall underscore vital elements of sacred space, namely that is "contested space." 54 Taking a similar posture of resistance, Ronald Rael and numerous artists have proposed designs that will transform the wall from a dystopian space of terror and intimidation into a utopian place of collaboration and flourishing. ${ }^{55}$ Well before Trump's election, Rael realized the inevitability of the construction of some kind of wall and this occasioned him to convene architects and artists to reimagine what the wall could be: a cactus wall, library wall, solar panel wall, or burrito wall where people can share meals. In late July we saw one such wall come to fruition in the installation of the "Teetertotter Wall" on the border between Ciudad Juarez and El Paso. ${ }^{56}$ Sacralization of space through the wall is incarnated in the Communion wall, a binational ritual of the Lord's Supper offered at San Diego's Friendship Park by Rev. John Fanestil of the United Methodist Church. ${ }^{57}$ We have yet to see the variegated ways that sacred meaning will be 
imputed onto and despite the imagined wall that Trump has now started to build.

We don't know how exactly the wall will play out, but we do know that Trump will be inextricably linked to the wall, his monument. A "big" wall that demonstrates Trump's role as protector and that honors sacrifices seems appropriate for the nation's leader who regularly alludes to others naming him among the greatest presidents ever. He himself declared, "Nobody's ever done a better job than I'm doing as president." 58 It only seems appropriate that his own monument would outsize those of the "greats," such as Washington and Lincoln who are indelibly enshrined in America's civil religion.

If civil religion was meant to unify the populace in support of their government, this effort to build a wall and protect it at all costs-even the cost of the unity of the peopleshould behoove us to conceptualize of Trump's brand of civil religion as uncivil religion. Trump's type of civil religion, specifically his wall monument, has proven to dramatically divide the country (and not to mention the North American continent, literally). Should the wall be built, few will forget that it is "Trump's Wall." As for his reputation as the greatest president of American (un)civil religion, the writing (to borrow from another biblical story) is already on the wall.

(C) Lloyd Barba

Lloyd Barba is an assistant professor of Religion at Amherst College and core faculty in Latinx and Latin American Studies. His book, Sowing the Sacred (under contract with Oxford University Press), renders a history of Mexican Pentecostals, race, and sacred space in the context of migrant labor in California's agricultural industry from 1916 to 1966. He currently serves as the co-chair of the History of Christianity unit of the American Academy of Religion.

\section{Citation Guide}

1. Lloyd D. Barba, "Trump’s Wall: A Monument of (Un)Civil Religion?" Mediation, MAVCOR Journal 3, no. 1 (2019), doi:10.22332/mav.med.2019.1

Barba, Lloyd D. "Trump's Wall: A Monument of (Un)Civil Religion?" Mediation. MAVCOR Journal 3, no. 1 (2019). doi:10.22332/mav.med.2019.1

\section{Notes}

1. Josh Barajas "In 3 Tweets, Trump Defends 'Beautiful' Confederate Monuments," PBS NewsHour, August 17, 2017, https://www.pbs.org/newshour/politics/in-3-tweets-trump-defends-beautifulconfederate-monuments 
2. Noah Caldwell and Audie Cornish, "Where Do Confederate Monuments Go After They Come Down?” NPR, August 5, 2018, https://www.npr.org/2018/08/05/633952187/ where-do-confederate-monuments-go-after-they-come-down

3. John Fea developed the notion of "court Evangelicals" in chapter 4 of John Fea, Believe Me: The Evangelical Road to Donald Trump (Grand Rapids: Eerdmans, 2018). Given the divisive nature of Trump's brand of civil religion, I hereafter prefer to use the term (un)civil religion, so as to allow for multiple readings of the term.

4. Robert N. Bellah, "Civil Religion in America," Daedalus 96, no. 1 (Winter 1967): 1-21.

5. Catherine Albanese, America: Religions and Religion, $5^{\text {th }}$ ed. (Boston, MA:

Wadsworth, 2013), 284-289; Richard Amesbury, "Religion and the Civic Imagination" The Immanent Frame, March 5, 2010, https://tif.ssrc.org/2010/03/05/religion-and-the-civic/; Phillip E. Hammond, Amanda Porterfield, James G. Mosley, and Jonathan D. Sarna, "Forum: American Civil Religion Revisited," Religion and American Culture: A Journal of Interpretation 4, no. 1 (Winter, 1994): 1-6; Charles Reagan Wilson, Baptized in Blood, $2^{\text {nd }}$ ed. (Athens, GA: University of Georgia Press, 2009).

6. Hammond et al., "Forum," 21; N. J. Demerath III and Ryhs H. Williams, "Civil Religion in an Uncivil Society," The Annals of the American Academy of Political and Social Science 480, (July 1985): 155 .

7. Robert Bellah, The Broken Covenant: American Civil Religion in Time of Trial, $2^{\text {nd }}$ ed. (Chicago: University of Chicago Press, 1992), ix.

8. Hammond et. al., "Forum," 21.

9. Robert Wuthnow, The Restructuring of American Religion (Princeton: Princeton University Press, 1988), 144-146.

10. Philip Gorski, American Covenant: A History of Civil Religion from the Puritans to the Present (Princeton: Princeton University Press, 2017).

11. Arthur Remillard, Southern Civil Religions (Athens, GA: University of Georgia Press, 2011).

12. Robert N. Bellah and Frederick E. Greenspahn, eds., Uncivil Religion: Interreligious Hostility in America (New York: Crossroad, 1987).

13. Reagan, Baptized in Blood, 1.

14. Ibid., 18-19. 
15. Booth Gunter, Jamie Kizzire, and Cindy Kent, "Whose Heritage?: Public Symbols of the Confederacy," Southern Poverty Law Center, April 21, 2016, https://www.splcenter.org/sites/default/files/com_whose_heritage.pdf

16. Lorraine Boissoneault, "What Will Happen to Stone Mountain, America's Largest Confederate Memorial," Smithsonian Magazine, August 22, 2017, https://www.smithsonianmag.com/history/what-will-happen-stone-mountainamericas-largest-confederate-memorial-180964588/

17. Kate Eschner, "The Memorial to Crazy Horse Has Been Under Construction for Almost 70 Years," Smithsonian, December 4, 2017, https://www.smithsonianmag.com/smart-news/memorial-crazy-horse-has-beenunder-construction-almost-70-years-180967377/

18. Ron Nixon and Linda Qiu, "Trump's Evolving Words on the Wall," New York Times, January 18, 2018, https://www.nytimes.com/2018/01/18/us/politics/trump-border-wall-immigration. $\underline{\mathrm{html}}$

19. Kate Morrissey, "Tear-Down of Border Wall Prototypes Underway,” The Los Angeles Times, February 27, 2019.

https://www.latimes.com/local/lanow/la-me-ln-border-wall-prototypes-torn-down20190227-story.html

20. "Full Text: Donald Trump Announces a Presidential Bid" The Washington Post, June 16, 2016, https://www.washingtonpost.com/news/post-politics/wp/2015/06/16/full-textdonald-trump-announces-a-presidential-bid/

21. "President Donald J. Trump's Address to the Nation on the Crisis at the Border," The White House, January 8, 2019, https://www.whitehouse.gov/briefings-statements/president-donald-j-trumps-addressnation-crisis-border/; "Trump: Border Security 'Sacred Obligation,”' BBC News, December 20, 2018, https://www.bbc.com/news/av/world-us-canada-46642820/donald-trump-us-bordersecurity-our-sacred-obligation

22. Deanna Paul, "Trump May Declare a National Emergency in the Border Wall Battle," The Washington Post, January 12, 2019, https://www.washingtonpost.com/politics/2019/01/12/trump-may-declare-nationalemergency-border-wall-battle-heres-what-that-means/

23. Sarah Pulliam Bailey, “God is not against Building Walls!' The Sermon Trump Heard from Jeffress before his Inauguration,” The Washington Post, January 20, 2017, https://www.washingtonpost.com/news/acts-of-faith/wp/2017/01/20/god-is-notagainst-building-walls-the-sermon-donald-trump-heard-before-his-inauguration/ 
24. Brendan Cole, "Evangelical Pastor Robert Jeffress Defends Trump's Border Wall: 'Heaven Itself Is Going to Have a Wall Around It,” Newsweek, January 10, 2019, https://www.newsweek.com/evangelical-pastor-robert-jeffress-defends-trumps-borderwall-heaven-itself-1286249

25. Bellah, "Civil Religion,” 10-11.

26. Dartunorro Clark, "Trump Holds White House Event Focused on 'American Victims of Illegal Immigration," NBC News, January 22, 2018, https://www.nbcnews.com/politics/white-house/trump-looks-shift-border-policydebate-american-victims-illegal-immigration-n885881

27. Ian Schwartz, "Trump at Border: Without The Wall There Will Be 'Death, A Lot Of Death” RealClearPolitics, January 10, 2019, https://www.realclearpolitics.com/ video/2019/01/10/trump at border without the wall there will be death a lot of death.html

28. Reagan, Baptized in Blood, 36.

29. Gorski, American Covenant.

30. On the conquest narratives and American religious nationalism see Gorski, American Covenant.

31. Jason De León, The Land of Open Graves: Living and Dying on the Migrant Trail (University of California Press, 2015); For information regarding the number and location of migrant deaths since January 1999, see https://humaneborders.org/

32. "Fundraiser by Brian Kolfage: We The People BUILT the Wall!" https://www. gofundme.com/TheTrumpWall

33. Kathryn Lofton, Consuming Religion (Chicago: University of Chicago Press, 2017), 38.

34. https://www.gofundme.com/TheTrumpWall

35. Ibid.

36. Andrew Hay, "Private Border Wall Construction Halts After New Mexico Town Protests," Reuters, May 29, 2019, https://www.reuters.com/article/us-usa-immigration-wall/private-border-wallconstruction-halts-after-new-mexico-town-protests-idUSKCN1SZ2LP

37. Fernando Romero, Hyperborder: The Contemporary U.S.-Mexico Border and Its Future (Princeton: Princeton Architectural Press, 2007). 
38. Remillard, Southern Civil Religions, 23.

39. Lofton, Consuming Religion, 37.

40. David Morgan "The Social Body of Belief," The Immanent Frame, January 15, 2010, https://tif.ssrc.org/2010/01/15/the-social-body-of-belief/

41. Terry Gross interview with Garrett Graff, "Journalist Digs Into Years Of Corruption, Dysfunction At Border Protection Agency," NPR, July 18, 2019, https://www.npr.org/2019/07/18/743028537/journalist-digs-into-years-of-corruptiondysfunction-at-border-protection-agency

42. This fundraiser was hosted on the official website of "We Build the Wall," see https://webuildthewall.us

43. Ibid.

44. Ebrahim Moosa, "Civil Religion and Beyond," The Immanent Frame, January 22, 2010, https://tif.ssrc.org/2010/01/22/civil-religion-and-beyond/

45. Ryan Harvey, "Sending the US Army to the Border Creates a 'War Atmosphere," The Nation, November 14, 2018, https://www.thenation.com/article/army-troop-deployment-mexico-bordercontractors/

46. Wesley Morgan, "2,100 More Troops Headed to the U.S.-Mexico Border, Pentagon Says,” Politico, July 17, 2019, https://www.politico.com/story/2019/07/17/2-100-more-troops-headed-to-the-usmexico-border-pentagon-says-1418838

James Laporta, "Exclusive: As More Troops Head to the U.S.-Mexico Border, Drones Designed for War Could be Going," Newsweek, August 9, 2019, https://www.newsweek.com/exclusive-more-troops-head-us-mexico-border-dronesdesigned-war-could-going-too-1453606 Courtney Kube and Julia Ainsley, "Trump Administration Wants to Keep Troops at U.S.-Mexico Border Through Sept. 2020,” NBC News, August 2, 2019, https://www.nbcnews.com/news/military/trump-administration-wants-keep-troops-us-mexico-border-through-n1038741

47. Terry Gross interview with Garrett Graff.

48. Ian Schwartz, "Trump on Border: 'Maybe They'll Call It the Trump Wall,'” RealClearPolitics, August 19, 2015, https://www.realclearpolitics.com/ video/2015/08/19/trump on border maybe theyll call it the trump wall.html

49. Mark Niquette, "About the Wall that Trump Said Mexico Would Be Paying for," The 
Washington Post, https://perma.cc/B9NM-LJG4. On the estimate of $\$ 70$ billion made by the U.S. Senate, see, "U.S. Senate Report: Wall Could Soar Toward $\$ 70$ Billion," U.S. Senate Committee on Homeland Security and Governmental Affairs, April 18, 2017, https://perma.cc/MPA2-H7M8

50. Donald J. Trump (@realDonaldTrump), “Wow! Big VICTORY on the Wall. The United States Supreme Court Overturns Lower Court Injunction, Allows Southern Border Wall to Proceed. Big WIN for Border Security and the Rule of Law!” Tweet, July 26, 2019, https://perma.cc/KB5U-ZH4R

51. Dror Ladin, “Supreme Court Order No ‘Big Victory’ for Trump’s Border Wall. The Fight Continues," American Civil Liberties Union, July 29 2019, https://perma. cc/998R-RWM5

52. Molly Hennessey-Fiske, "Arizona Tribe Refuses Trump's Wall, But Agrees to Let Border Patrol Build Virtual Barrier," LA Times, May 9, 2019, https://perma.cc/3GPT$7 \mathrm{G} 2 \mathrm{~F}$

53. Jeremy Raff, "The Chapel at the Border," The Atlantic, February 24, 2019, https:// perma.cc/D8NU-BCDA

54. David Chidester and Edward T. Linenthal, "Introduction," in American Sacred Space, eds. David Chidester and Edward T. Linenthal (Bloomington, IN: Indiana University Press), 15-20.

55. Ronald Rael, Borderwall as Architecture: A Manifesto for the U.S.-Mexico Boundary (University of California Press, 2017).

56. Eli Rosenberg, "Two Artists Built Seesaws across the U.S.-Mexico Border: Then the Video of Kids Playing on Them Went Viral," The Washington Post, July 30, 2019, https://perma.cc/5EKB-MM3T

57. “Joining Families at the Border: Rev. John Fanestil,” https://perma.cc/FU6M-643D

58. Philip Bump, “Trump: Nobody's Ever Done a Better Job than I'm Doing as President," The Washington Post, September 4, 2018, https://perma.cc/7FQU-LL5X 


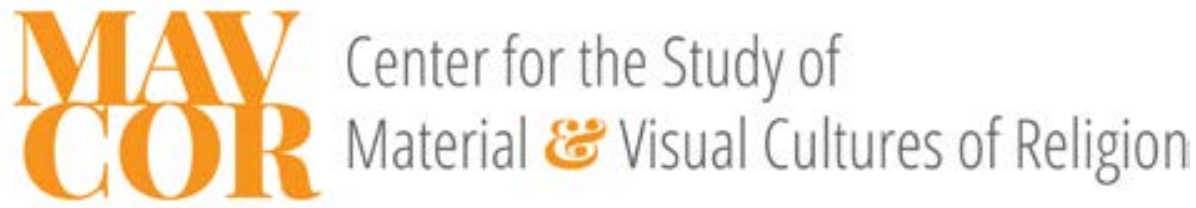

\section{Yale}

Copyright 2016 Yale University All rights reserved.

MAVCOR Joumal is a born-digital, double-blind peer-reviewed publication of the Center for the Study of Material and Visual Cultures of Religion at Yale University (mavcor.yale.edu). 